
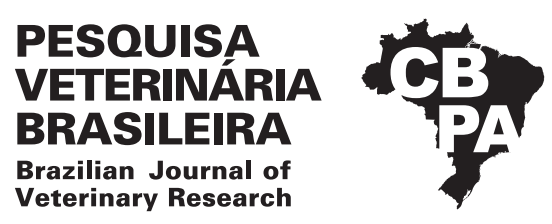

Pesq. Vet. Bras. 39(1):85-92, janeiro 2019 DOI: 10.1590/1678-5150-PVB-5798

ISSN 0100-736X (Print)

ISSN 1678-5150 (Online)

\title{
DNA damage and primordial follicle activation after in vitro culture of sheep ovarian cortex in Morus nigra leaf extract ${ }^{1}$
}

\author{
Bruna B. Gouveia'²* (D), Ricássio S. Barberino², Vanúzia G. Menezes², \\ Taís J.S. Macedo², Agnes Y.P. Cavalcante², Rodrigo J.S. Gonçalves², Jackson R.G.S. \\ Almeida $^{3}$ and Maria Helena T. Matos ${ }^{2}$
}

\begin{abstract}
Gouveia B.B., Barberino R.S., Menezes V.G., Macedo T.J.S., Cavalcante A.Y.P., Gonçalves R.J.S., Almeida J.R.G.S. \& Matos M.H.T. 2019. DNA damage and primordial follicle activation after in vitro culture of sheep ovarian cortex in Morus nigra leaf extract. Pesquisa Veterinária Brasileira 39(1):85-92. Colegiado de Medicina Veterinária, Laboratório de Biologia Celular, Citologia e Histologia, Universidade Federal do Vale do São Francisco, Rodovia BR-407 Km 12, Lote 543, Projeto de Irrigação Nilo Coelho s/n C1, Petrolina, PE 56300-990, Brazil. E- mail: bruna.bortoloni@gmail.com

This study evaluated the effect of Morus nigra leaf extract, with or without supplementation, on morphology, activation and DNA damage of preantral follicles cultured within sheep ovarian tissue. Ovaries were collected and divided into fragments, being one fixed for histological and Terminal deoxynucleotidyl transferase (TdT) mediated dUTP nick-end labeling (TUNEL) analysis (fresh control). The remaining fragments were cultured for 7 days in alpha minimum essential media ( $\alpha$-MEM) supplemented with bovine serum albumin (BSA), insulin, transferrin, selenium, glutamine, hypoxanthine and ascorbic acid ( $\alpha-\mathrm{MEM}^{+}$; control medium) or into medium composed of M. nigra extract without supplements $(0.1 ; 0.2$ or $0.4 \mathrm{mg} / \mathrm{mL})$ or supplemented with the same substances described above for $\alpha-\mathrm{MEM}^{+}\left(\mathrm{MN} 0.1^{+} ; 0.2^{+}\right.$or $\left.0.4^{+} \mathrm{mg} / \mathrm{mL}\right)$. Then, tissues were destined to histological and TUNEL analysis. The $\alpha-\mathrm{MEM}^{+}$treatment had more morphologically normal follicles than all $M$. nigra extract treatments. However, $\alpha-\mathrm{MEM}^{+}$ treatment also showed signs of atresia because the percentage of TUNEL positive cells was similar in $\alpha-\mathrm{MEM}^{+}$and in $0.1 \mathrm{mg} / \mathrm{mL}$ M. nigra without and with supplements. Moreover, a reduction in the primordial follicles and an increase in the growing ones were observed in all treatments, except $0.2 \mathrm{mg} / \mathrm{mL} M$. nigra. In conclusion, the follicles cultured at $0.1 \mathrm{mg} / \mathrm{mL} M$. nigra extract were in good condition and able to continue their development, as demonstrated by the same rates of DNA damage and follicular activation as the control medium.
\end{abstract}

INDEX TERMS: DNA damage, Morus nigra, follicle growth, in vitro culture, ovarian cortex, leaf extraction, Oocyte, medicinal plant, apoptosis, ovarian tissue culture, sheep.

RESUMO.- [Dano ao DNA e ativação do folículo primordial após a cultivo in vitro do córtex ovariano de ovelha em extrato de folha de Morus nigra.] Este estudo avaliou o efeito do extrato das folhas de Morus nigra, com ou sem suplementos, sobre a morfologia, a ativação e o dano ao DNA de folículos

\footnotetext{
${ }^{1}$ Received on April 10, 2018.

Accepted for publication on July 16, 2018.

${ }^{2}$ Núcleo de Biotecnologia Aplicado ao Desenvolvimento Folicular Ovariano, Universidade Federal do Vale do São Francisco (Univasf), Rodovia BR-407 Km 12, Lote 543, Projeto de Irrigação Nilo Coelho s/n C1, Petrolina, PE 56300-990, Brazil. *Corresponding author: bruna.bortoloni@gmail.com

${ }^{3}$ Centro de Estudos e Pesquisas sobre Plantas Medicinais, Universidade Federal do Vale do São Francisco (Univasf), Campus Petrolina, Av. José de Sá Maniçoba s/n, Centro, Petrolina, PE 56304-205.
}

pré-antrais cultivados inclusos em tecido ovariano. Os ovários foram coletados e divididos em fragmentos, sendo um fixado para análise histológica e ensaio de marcação de terminações dUTP mediada por desoxinucleotidil transferase terminal (TUNEL) (controle fresco). Os fragmentos restantes foram cultivados durante 7 dias em meio essencial mínimo alfa $(\alpha$-MEM) suplementado com albumina sérica bovina (BSA), insulina, transferrina, selênio, glutamina, hipoxantina e ácido ascorbico ( $\alpha-\mathrm{MEM}^{+}$; meio controle) ou em meio composto de extrato de M. nigra sem suplementos $(0,1 ; 0,2$ or $0,4 \mathrm{mg} / \mathrm{mL})$ ou suplementado com as mesmas substâncias descritas para $\alpha-\mathrm{MEM}^{+}\left(\mathrm{MN} 0,1^{+} ; 0,2^{+}\right.$or $\left.0,4^{+} \mathrm{mg} / \mathrm{mL}\right)$. Então, os tecidos foram destinados à análise histológica e TUNEL. 0 tratamento do 
$\alpha-\mathrm{MEM}^{+}$apresentou mais folículos morfologicamente normais que todos os tratamentos do extrato de M. nigra. No entanto, o tratamento com $\alpha$-MEM ${ }^{+}$também mostrou sinais de atresia, pois a porcentagem de células TUNEL positivas foi semelhante em $\alpha-\mathrm{MEM}^{+}$e em $0,1 \mathrm{mg} / \mathrm{mL}$ M. nigra sem e com suplementos. Além disso, observou-se uma redução nos folículos primordiais e um aumento nos folículos em crescimento em todos os tratamentos, exceto $0,2 \mathrm{mg} / \mathrm{mL} M$. nigra. Em conclusão, os folículos cultivados com $0,1 \mathrm{mg} / \mathrm{mL}$ de extrato de M. nigra estavam em boas condições e aptos a continuar seu desenvolvimento, como demonstrado pelas taxas de dano ao DNA e de ativação folicular semelhantes ao meio controle.

TERMOS DE INDEXAÇÃO: DNA, folículo primordial, cultivo in vitro, córtex ovariano, ovelha, extrato de folha, Morus nigra, crescimento folicular, Oócito, planta medicinal, apoptose, cultivo de tecido ovariano, ovinos.

\section{INTRODUCTION}

To maximize the reproductive potential of fresh and cryopreserved ovarian tissue it is necessary to develop culture systems that support the activation of primordial follicles as this is the most abundant stage of follicle development present in mammalian ovaries. Therefore, culture of ovarian tissue would support the initiation and maintenance of primordial and primary follicle growth to the secondary stage of development, which could be isolated and cultured to the antral stage, supporting oocyte growth to full size. The development of these technologies in association with ovarian cryopreservation holds many possibilities for clinical practice, animal production technology, and can also be used as a research tool to investigate the biology and toxicology of oogenesis in both animals and humans (Picton et al. 2008).

To achieve this goal, further optimization of the culture medium is required to sustain high levels of primordial follicle activation and growth in vitro. Studies have shown that $\alpha$-Minimum Essential Medium ( $\alpha$-MEM) to which different supplements (hormones, antioxidants and/or growth factors) have been added promoted goat (Berrocal et al. 2016) and sheep (Santos et al. 2014) follicular development in vitro. However, in order to reduce the costs of the media and supplements used for follicle culture, extracts of medicinal plants have attracted increasing attention as natural compounds with antioxidant properties (Barberino et al. 2016, Gouveia et al. 2016).

Morus nigra L. is an arboreal plant found in temperate to subtropical regions of the Northern hemisphere to the tropics of the Southern hemisphere (Ercisli \& Orhan 2007), being widely used in folk medicine as anti-inflammatory, diuretic, antioxidant and antidiabetic (Nickavar \& Mosazadeh 2010, Radojkovic et al. 2016). Phenolic compounds with antioxidant activities (flavonoids, stilbenes, coumarins, rutin, isoquercetin and kaempferitrin) have been isolated from the bark and leaves of this plant (Mazimba et al. 2011, Cavalcante et al. 2017), which may reduce the levels of reactive oxygen species (ROS) and modulate the expression of antioxidant enzymes in different cell types (Mata-Campuzano et al. 2012, Nafees et al. 2015).

A recent study by our team has shown that $0.05 \mathrm{mg} / \mathrm{mL}$ of M. nigra leaf extract can be used as a preservation medium for ovine ovarian tissue at $4^{\circ} \mathrm{C}$, maintaining follicular survival and decreasing DNA fragmentation in comparison to control medium (MEM) (Cavalcante et al. 2017). Other study showed that M. nigra extract has a protective action against peroxidative damage to biomembranes and biomolecules of rats and human (Naderi et al. 2004). Knowing that oxidative stress initiates apoptosis through the increase of ROS after the culture of follicular cells (Devine et al. 2012), it can be hypothesized that $M$. nigra extract and its antioxidant properties may be a useful and cheap substitute for follicle culture medium.

As there are no reports in which $M$. nigra extract has been used as a culture medium for ovine ovarian tissue, this study was conducted to evaluate the effect of this extract on in vitro morphology, primordial follicle activation and DNA fragmentation of follicles cultured within slices of the ovine ovarian cortex. Furthermore, the effectiveness of the addition of supplements to M. nigra leaf extract was studied.

\section{MATERIALS AND METHODS}

Unless indicated, supplements and chemicals used in the present study were purchased from Sigma Chemical Co. (St Louis/MO, USA). This project was approved by the Ethics Committee on Human and Animal Studies of Federal University of São Francisco Valley (protocol No. 0008/040713).

Plant material and extract preparation. Fresh leaves of Morus nigra were collected in Petrolina (09 $23^{\circ} 55^{\prime \prime}$ S and 38-40 $30^{\prime} 03^{\prime \prime} \mathrm{W}$, Pernambuco, Brazil). A voucher specimen (1764) is deposited at the Herbário Vale do São Francisco (HVASF) of the Universidade Federal do Vale do São Francisco. The leaves were dried in an oven at $40^{\circ} \mathrm{C}$ and pulverized and extracted at room temperature with $95 \%$ ethanol (Vetec, Duque de Caxias-RJ, Brazil) for $72 \mathrm{~h}$. The extract was dried at $45^{\circ} \mathrm{C}$ using a rotavapor and this method yields approximately $10 \%$, thus obtaining the crude ethanolic extract of the leaves of M. nigra. Thereafter, the extract was dissolved in $0.9 \%$ saline solution, corresponding to concentrations of $0.1 ; 0.2$ or $0.4 \mathrm{mg} / \mathrm{mL}$.

Ovaries collection. Ovarian cortical tissues ( $\mathrm{n}=8$ ovaries) were collected at a local abattoir from four adult (1-3 years old) mixedbreed sheep. Immediately postmortem, pairs of ovaries were washed once in $70 \%$ alcohol (Dinâmica, São Paulo, Brazil) and then twice in Minimum Essential Medium buffered with HEPES (MEM-HEPES) and supplemented with antibiotics $(100 \mu \mathrm{g} / \mathrm{mL}$ penicillin and $100 \mu \mathrm{g} / \mathrm{mL}$ streptomycin). Next, the ovaries were transported within $1 \mathrm{~h}$ to the laboratory in tubes containing MEM-HEPES with antibiotics at $4^{\circ} \mathrm{C}$ (Chaves et al. 2008).

Experimental design for the in vitro culture. The in vitro culture was performed according to a previous study (Santos et al. 2014). In the laboratory, the surrounding fatty tissues and ligaments were stripped from the ovaries; large antral follicles and corpora lutea were removed. The pair of ovaries from each animal were divided into 8 fragments approximately $3 \times 3 \mathrm{~mm}(1 \mathrm{~mm}$ thick), under sterile conditions. For each animal, one slice of tissue was randomly selected and immediately fixed for histological and TUNEL analysis (fresh control). The remaining slices of ovarian cortex were cultured individually in $1 \mathrm{~mL}$ of culture medium in 24-well culture dishes for 7 days; the culture conditions were $39^{\circ} \mathrm{C}$ in an atmosphere of $5 \% \mathrm{CO}_{2}$ in air. The base culture medium (control) consisted of $\alpha$-MEM (Gibco, Invitrogen, Karlsrushe, Germany, pH 7.2-7.4) supplemented with $10 \mathrm{ng} / \mathrm{mL}$ insulin, $5.0 \mu \mathrm{g} / \mathrm{mL}$ transferrin, $5.0 \mathrm{ng} / \mathrm{mL}$ sodium selenite, $2 \mathrm{mM}$ glutamine, $2 \mathrm{mM}$ hipoxanthine, $1.25 \mathrm{mg} / \mathrm{mL}$ BSA and $50 \mu \mathrm{g} / \mathrm{mL}$ ascorbic acid and then referred as $\alpha-\mathrm{MEM}^{+}$. To test the effect of the plant extract, ovarian fragments were cultured in $\alpha-\mathrm{MEM}^{+}$(control medium) or in medium composed of different concentrations of Morus nigra extract (M. nigra diluted in saline solution) without supplements (MN $0.1,0.2$ or $0.4 \mathrm{mg} / \mathrm{mL}, \mathrm{pH} 7.2-7.4$ ) or $M$. nigra 


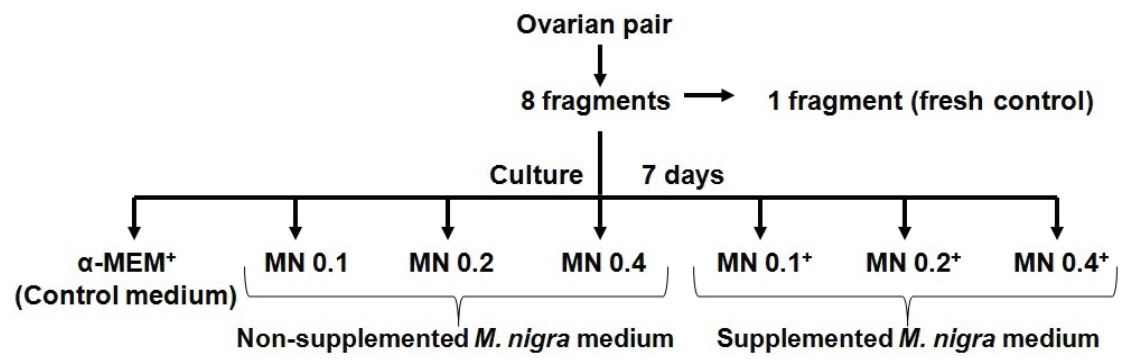

Fig.1. General experimental protocol for in situ culture of ovine preantral follicles in Morus nigra extract.

extract supplemented with the same substances described above for $\alpha$-MEM ${ }^{+}$supplementation. The M. nigra supplemented medium was named MN $0.1^{+} ; 0.2^{+}$or $0.4^{+} \mathrm{mg} / \mathrm{mL}$ (Fig.1). The culture medium was replenished every other day. Each treatment was repeated 4 times, thus using the ovaries of 4 different animals.

Morphological analysis of preantral follicles. Ovarian fragments from the fresh control and each cultured treatment were fixed individually in 4\% buffered paraformaldehyde (Dinâmica, São Paulo, Brazil) for 18 hours. Subsequently, fragments were dehydrated in a graded series of ethanol (Dinâmica, São Paulo, Brazil), clarified with xylene (Dinâmica, São Paulo, Brazil) and embedded in paraffin wax (Dinâmica, São Paulo, Brazil). Tissues were serially sectioned at a thickness of $5 \mu \mathrm{m}$ and sections were stained using standard protocols with hematoxylin-eosin (Vetec, Duque de Caxias/RJ, Brazil). Sections were examined by light microscopy (Nikon, Tokyo, Japan) at 400× magnification (Cavalcante et al. 2017).

Preantral follicles were counted and evaluated in the section where the oocyte nucleus was visible. These follicles were classified individually, according to the quality aspect, as histologically normal when an intact oocyte is present and surrounded by granulosa cells that are well organized in one or more layers and have no pyknotic nuclei. Atretic follicles were defined as those with a retracted oocyte, pyknotic nucleus, and/or disorganized granulosa cells detached from the basement membrane. Overall, 120 follicles were evaluated in each treatment ( 30 follicles per treatment $\mathrm{x} 4$ replicates $=120$ follicles), totaling 960 preantral follicles.

The evaluation of follicular activation (transition from primordial to growing follicles) was performed by quantifying normal follicles at different classes of follicular development (Silva et al. 2004), as primordial (one layer of flattened granulosa cells around the oocyte) or growing follicles (intermediate: one layer of flattened to cuboidal granulosa cells; primary: one layer of cuboidal granulosa cells, and secondary: two or more layers of cuboidal granulosa cells around the oocyte). The proportion of primordial and growing follicles was calculated at day 0 (fresh control) and after 7 days of culture.

Assessment of DNA fragmentation by TUNEL assay. Terminal deoxynucleotidyl transferase (TdT) mediated dUTP nick-end labeling (TUNEL) assay was used for a more in-depth evaluation of ovine preantral follicle quality before (fresh control) and after culture in the different media. TUNEL was performed using a commercial kit (In Situ Cell Death Detection Kit, Roche Diagnostics Ltd., Indianapolis, USA) following the manufacturer's protocol and as previously described (Santos et al. 2014), with some modifications. Briefly, sections $(5 \mu \mathrm{m})$ mounted on glass slides were deparaffinized and rehydrated through graded alcohols, then rinsed in PBS ( $\mathrm{pH} 7.2)$. The slides were incubated in citrate buffer (Dinâmica) at $95^{\circ} \mathrm{C}$ in a deckloaking chamber (Biocare, Concord/CA, USA) for 40min to retrieve antigenicity, and endogenous peroxidase activity was prevented by incubation with 3\% $\mathrm{H}_{2} \mathrm{O}_{2}$ (Dinâmica) and methyl ethanol (QEEL, São Paulo, Brazil) for $10 \mathrm{~min}$. After rinsing in Tris buffer (Dinâmica), the sections were incubated with TUNEL reaction mixture at $37^{\circ} \mathrm{C}$ for $1 \mathrm{~h}$. Then, the specimens were incubated with Converter-POD in a humidified chamber at $37^{\circ} \mathrm{C}$ for $30 \mathrm{~min}$. The DNA fragmentation was revealed by incubation of the tissues with diaminobenzidine (DAB; 0.05\% DAB in Tris/ $\mathrm{HCl} \mathrm{pH} \mathrm{7.6,} \mathrm{0.03 \%} \mathrm{H}_{2} \mathrm{O}_{2}$ ) during $1 \mathrm{~min}$. Finally, sections were counterstained with Harry's haematoxylin in a dark chamber at room temperature for $1 \mathrm{~min}$, dehydrated in ethanol, cleared in xylene, and mounted with balsam (Dinâmica). For negative controls (reaction controls), slides were incubated with label solution (without terminal deoxynucleotidyl transferase enzyme) instead of TUNEL reaction mixture.

Only follicles that contained an oocyte nucleus were analyzed by TUNEL assay (Santos et al. 2014). The number of brown TUNEL positive cells (oocyte and granulosa cells) was counted in ten randomly fields per treatment using Image-Pro Plus ${ }^{\circledR}$ software. The percentage of DNA fragmentation was calculated as the number of TUNEL-positive cells out of the total number of cells ( $\mathrm{x} 100$ ).

Statistical analysis. Percentages of morphologically normal follicles and follicular activation were submitted to ANOVA and the Tukey's test was applied for comparison among treatments. Data from TUNEL-positive cells were submitted Chi-squared test and expressed as percentages. Differences were considered to be statistically significant when $\mathrm{P}<0.05$.

\section{RESULTS}

\section{Follicular morphology and development after in vitro culture}

The preantral follicles from the control tissue showed centrally located oocytes and granulosa cells surrounded by normal intact basement membranes (Fig.2A). Normal follicles could also be observed after culture in control medium (Fig.2B). However, after 7 days of culture in $0.2 \mathrm{mg} / \mathrm{mL}$ of Morus nigra extract without supplements, atretic follicles with a retracted oocyte and disorganized granulosa cells could be observed (Fig.2C).

The percentage of morphologically normal follicles (follicular survival) decreased $(\mathrm{P}<0.05)$ after 7 days of culture in all treatments, compared to the fresh control (76\%; Fig.3). In addition, there were more $(\mathrm{P}<0.05)$ morphologically normal follicles in $\alpha-\mathrm{MEM}^{+}(53.5 \%)$ than in $M$. nigra extract (average of $40.3 \%$ ). However, there was no significant difference in the rate of follicular survival among the $M$. nigra concentrations, with or without supplements ( $\mathrm{P}>0.05)$.

In all culture conditions, a significant reduction in the percentage of primordial follicles, reflecting an increase in the percentage of growing ones, was observed in all treatments 


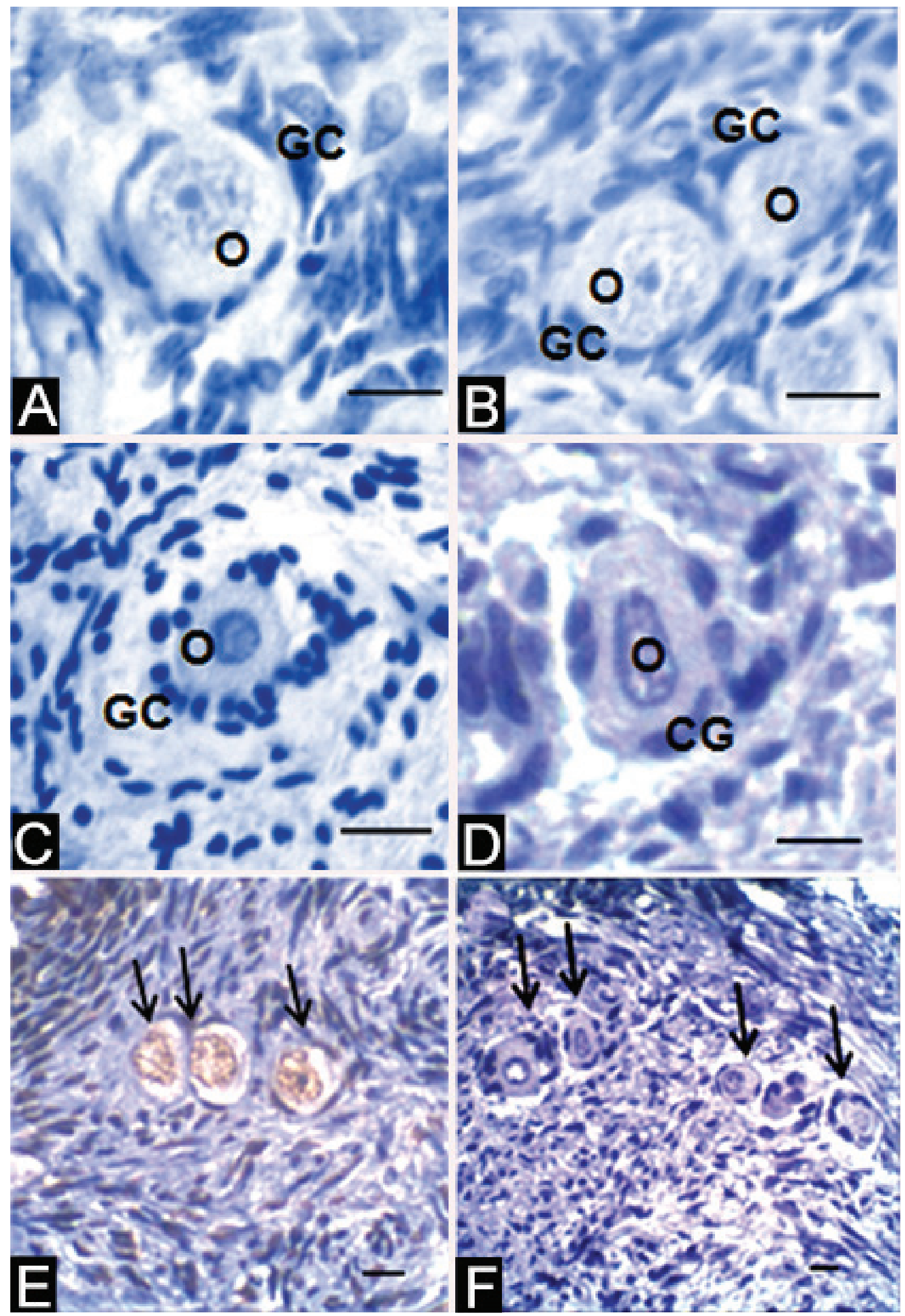

Fig.2. Histological sections of ovine ovarian fragments showing (A) morphologically normal follicles in the fresh control and (B) normal follicle after 7 days of culture in $\alpha-\mathrm{MEM}^{+}$or (C) atretic follicle in $0.2 \mathrm{mg} / \mathrm{mL}$ Morus nigra extract without supplements. (D) Normal preantral follicle in $0.1 \mathrm{mg} / \mathrm{mL} M$. nigra extract, DNA damage follicle in $0.4 \mathrm{mg} / \mathrm{mL} M$. nigra extract (E) and negative control (F). (E,F) TUNEL-positive cells detection in ovine ovarian tissue after 7 days of culture. $0=$ oocyte, GC = granulosa cell. Arrows indicate the follicles. TUNEL counterstained by hematoxylin, bar $=30 \mu \mathrm{m}$. 


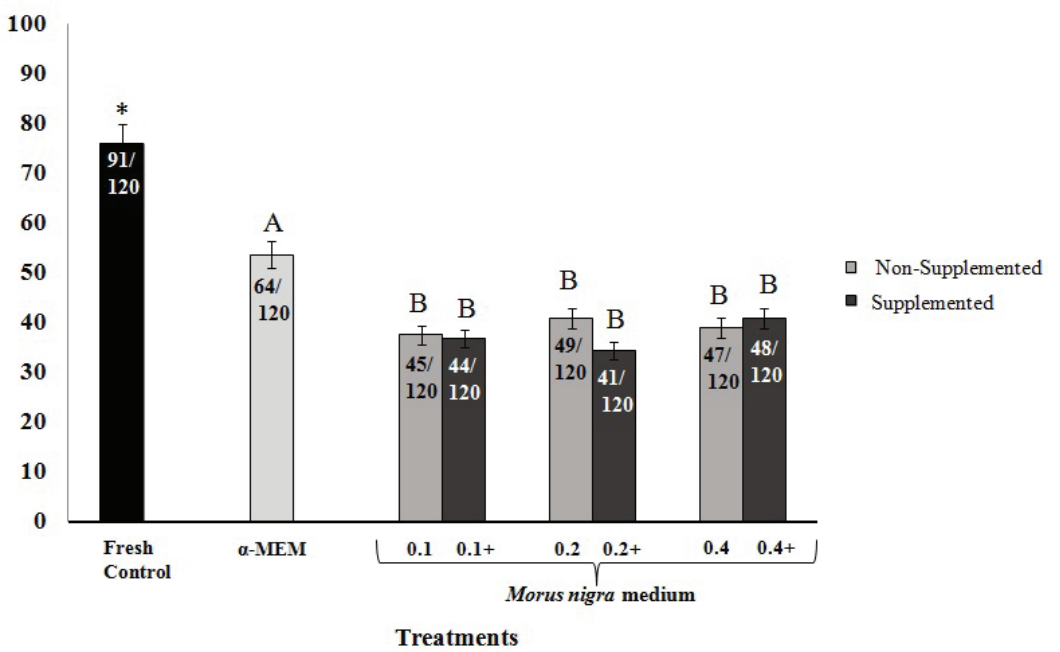

Fig.3. Percentages (mean \pm SEM) of morphologically normal follicles in the fresh control and after culture in $\alpha$-MEM or Morus nigra extract. MN $0.1=0.1 \mathrm{mg} / \mathrm{mL}$ non-supplemented $M$. nigra extract, $\mathrm{MN} 0.1^{+}=0.1 \mathrm{mg} / \mathrm{mL}$ supplemented $M$. nigra extract, $\mathrm{MN} 0.2=0.2 \mathrm{mg} / \mathrm{mL}$ non-supplemented $M$. nigra extract, $\mathrm{MN} 0.2^{+}=0.2 \mathrm{mg} / \mathrm{mL}$ supplemented $M$. nigra extract, MN $0.4=0.4 \mathrm{mg} / \mathrm{mL}$ non-supplemented M. nigra extract, $\mathrm{MN} 0.4^{+}=0.4 \mathrm{mg} / \mathrm{mL}$ supplemented $M$. nigra extract. * Differs significantly from fresh control $(\mathrm{P}<0.05) ;{ }^{\mathrm{A}, \mathrm{B}}$ different letters denote significant differences among treatments (different media, $\mathrm{P}<0.05$ ).

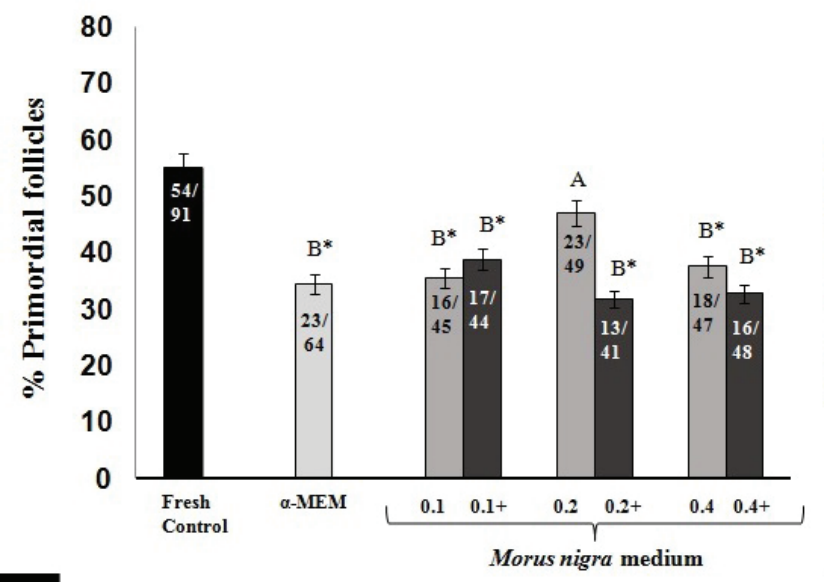

A

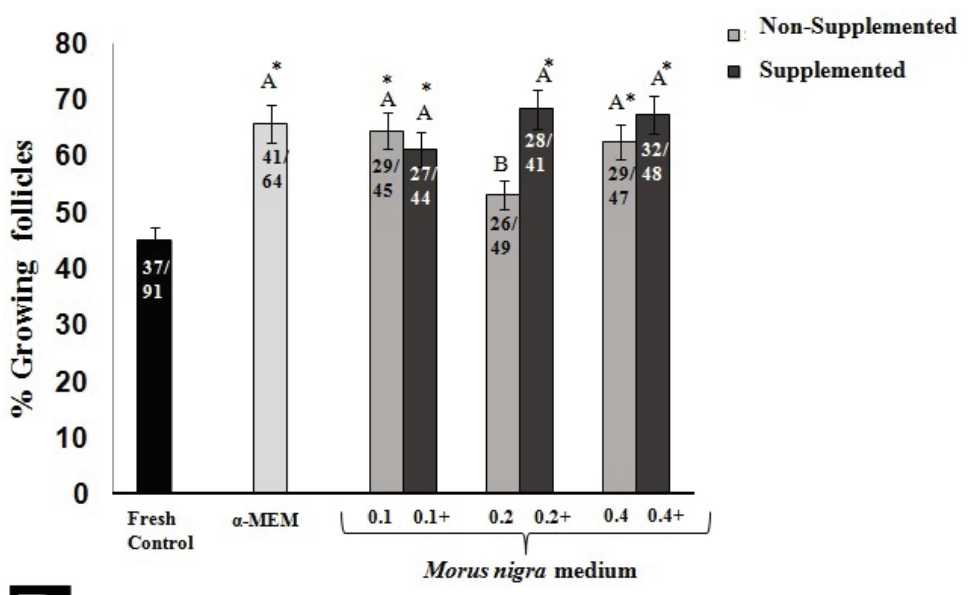

Treatments

Fig.4. Percentages (mean \pm SEM) of (A) normal primordial and (B) growing follicles in the fresh control and after 7 days of in vitro culture in $\alpha$-MEM or Morus nigra extract. MN $0.1=0.1 \mathrm{mg} / \mathrm{mL}$ non-supplemented $M$. nigra extract, $\mathrm{MN} 0.1^{+}=0.1 \mathrm{mg} / \mathrm{mL}$ supplemented $M$. nigra extract, $\mathrm{MN} 0.2=0.2 \mathrm{mg} / \mathrm{mL}$ non-supplemented M. nigra extract, $\mathrm{MN} 0.2^{+}=0.2 \mathrm{mg} / \mathrm{mL}$ supplemented $M$. nigra extract, $\mathrm{MN} 0.4=0.4 \mathrm{mg} / \mathrm{mL}$ non-supplemented $M$. nigra extract, $\mathrm{MN} 0.4^{+}=0.4 \mathrm{mg} / \mathrm{mL}$ supplemented $M$. nigra extract. * Differs significantly from fresh control $(\mathrm{P}<0.05) ;{ }^{\mathrm{A}, \mathrm{B}}$ different letters denote significant differences among treatments $(\mathrm{P}<0.05)$.

compared to fresh control group, except in ovarian tissue cultured in $0.2 \mathrm{mg} / \mathrm{mL}$ of M. nigra extract without supplements (Fig.4).

\section{DNA fragmentation after culture}

Ovarian follicles cultured in $0.1 \mathrm{mg} / \mathrm{mL}$ of $M$. nigra without supplements did not show or showed less TUNEL-positive cells (Fig.2D). Nevertheless, oocyte DNA damage was commonly found after culture in $0.4 \mathrm{mg} / \mathrm{mL}$ of $M$. nigra without supplements (Fig.2E). Negative controls did not show staining for TUNEL analysis (Fig.2F).
The percentage of TUNEL-positive cells in ovine preantral follicles before and after in vitro culture is shown in Figure 5. Culture of ovarian tissue for 7 days increased $(\mathrm{P}<0.05)$ the percentage of TUNEL-positive cells in all treatments compared to the fresh control. The percentage of DNA fragmentation in follicles cultured in $\alpha-\mathrm{MEM}^{+}$was similar $(\mathrm{P}>0.05)$ to that observed in $0.1 \mathrm{mg} / \mathrm{mL}$ of $M$. nigra extract without or with supplements. Nevertheless, culture of follicles in 0.2 or $0.4 \mathrm{mg} / \mathrm{mL}$ of $M$. nigra (in the absence or presence of supplements) increased $(\mathrm{P}<0.05)$ the percentage of TUNEL-positive cells when compared to other treatments. 


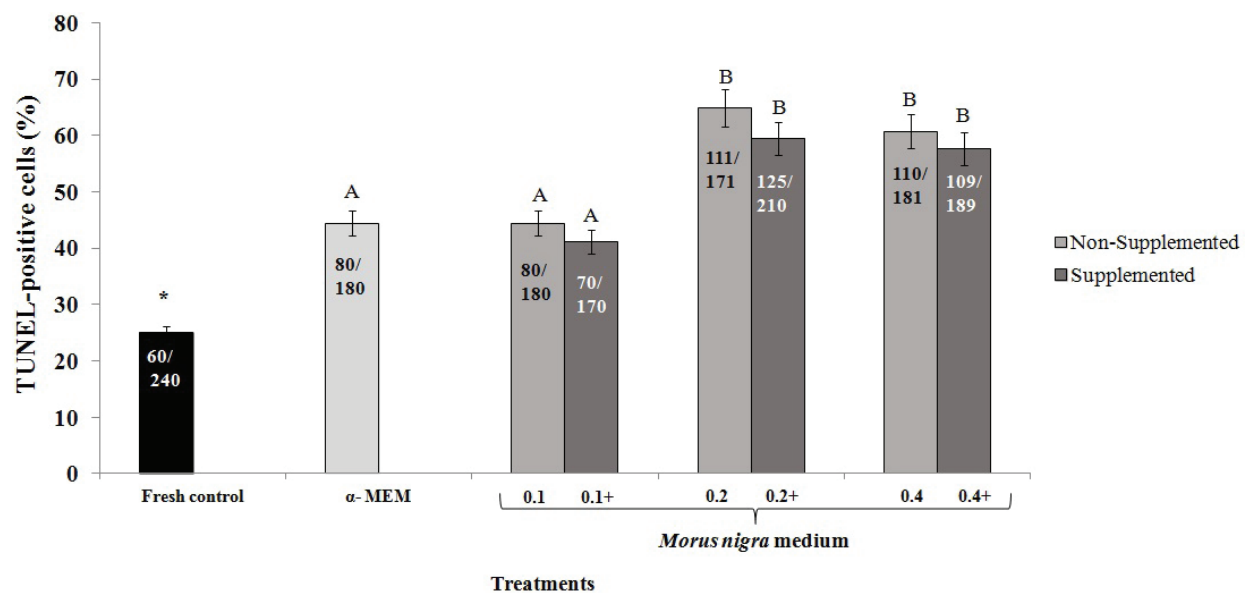

Fig.5. Percentage of total of TUNEL-positive cells in the fresh control, in $\alpha$-MEM or in Morus nigra extract. MN $0.1=0.1 \mathrm{mg} / \mathrm{mL}$ non-supplemented M. nigra extract, $\mathrm{MN} 0.1^{+}=0.1 \mathrm{mg} / \mathrm{mL}$ supplemented $M$. nigra extract, $\mathrm{MN} 0.2=0.2 \mathrm{mg} / \mathrm{mL}$ non-supplemented $M$. nigra extract, MN $0.2^{+}=0.2 \mathrm{mg} / \mathrm{mL}$ supplemented $M$. nigra extract, $\mathrm{MN} 0.4=0.4 \mathrm{mg} / \mathrm{mL}$ non-supplemented $M$. nigra extract, $\mathrm{MN} 0.4^{+}=0.4 \mathrm{mg} / \mathrm{mL}$ supplemented M. nigra extract. * Differs significantly from fresh control $(\mathrm{P}<0.05)$; ${ }^{\mathrm{A} B}$ different letters denote significant differences among treatments $(\mathrm{P}<0.05)$.

\section{DISCUSSION}

The present study evaluated for the first time the effect of Morus nigra leaf extract as a culture medium for ovine preantral follicles. The control medium $\left(\alpha-\mathrm{MEM}^{+}\right)$showed more histologically normal follicles than all M. nigra concentrations, in the absence or presence of supplements. The $\alpha-\mathrm{MEM}^{+}$is a complex medium containing electrolytes, antioxidants, amino acids, energy substrates, vitamins, and it has been routinely used as a base medium in the in vitro culture systems for preantral follicles (bubaline: Gupta et al. 2008, canine: Serafim et al. 2010, caprine: Magalhães et al. 2011, equine: Haag et al. 2013, ovine: Santos et al. 2014). Moreover, the addition of supplements to $\alpha$-MEM seems to be important for the maintenance of follicular survival after culture (Silva et al. 2004, Peng et al. 2010, Gouveia et al. 2016).

Although the follicles cultured in $\alpha$-MEM were classified as being of good morphology, this treatment showed the same rate of TUNEL-positive cells as $0.1 \mathrm{mg} / \mathrm{mL}$ of $M$. nigra extract. It is noteworthy that classification by traditional microscope observation is more subjective for quality assessment than ideally desired. Moreover, nuclear apoptosis at an early stage is difficult to identify with routine Haematoxylin-Eosin staining (Wang \& Roy 2007). Nevertheless, the TUNEL assay of labeling fragmented DNA has been used as a valid method for identifying cell death (Luyckx et al. 2014, Furlong et al. 2015). As DNA fragmentation in follicular cells could be detectable before other morphological and biochemical signs of degeneration (Sreejalekshmi et al. 2011), the DNA damage in follicles cultured in the control medium ( $\alpha$-MEM) was only noticeable after TUNEL analysis.

On the other hand, reduced DNA fragmentation in the medium composed of $0.1 \mathrm{mg} / \mathrm{mL}$ of $M$. nigra (without or with supplements), compared to other plant concentrations, and could be explained by compounds present in the extract used, which contains rutin, isoquercetin and kaempferitrin (Cavalcante et al.2017). These substances are flavonoids, a large group of polyphenolic compounds found in many plant-based foods, with antioxidant properties (Moretti et al. 2012).
More specifically, rutin decreased lipid peroxidation, ROS and DNA fragmentation in thawed deer spermatozoa after incubation at $37^{\circ} \mathrm{C}$ (Mata-campuzano et al. 2012) and can be used as the single antioxidant present in the base medium during in vitro culture of ovine secondary follicles, maintaining follicular viability and increasing GSH levels (Lins et al. 2017). Isoquercetin protects neuroblastome from the oxidative damage in vitro (Soundararajan et al. 2008), being described as anti-inflammatory and antiapoptotic factor (Wang et al. 2013). Moreover, kaempferitrin inhibits mieloperoxidase, a cytosolic enzyme that participates in ROS production in neutrophils (Regasini et al. 2008). It can be suggested that these three natural antioxidants may act isolated or in association with each other or with substances added to the medium to reduce the DNA damage in preantral follicles cultured in $0.1 \mathrm{mg} / \mathrm{mL}$ of $M$. nigra.

Nevertheless, in high concentrations antioxidants can become prooxidants (Carocho \& Ferreira 2013). Therefore, it is possible that higher concentrations $(0.2$ or $0.4 \mathrm{mg} / \mathrm{mL})$ of $M$. nigra have potentiated the cytotoxic effect of some compounds, increasing the rates of DNA damage. A previous study has shown that in vitro culture with $1000 \mu \mathrm{g} / \mathrm{mL}$ or $666 \mu \mathrm{g} / \mathrm{mL}$ of M. nigra extract after 18 or $72 \mathrm{~h}$, respectively, increased caspases-3/7 activity in human prostate cancer cells (Turan et al. 2017).

In the current study, all treatments promoted primordial follicle activation, except $0.2 \mathrm{mg} / \mathrm{mL}$ of $M$. nigra without supplements. Others authors have also demonstrated follicular activation using the supplemented $\alpha$-MEM (Santos et al. 2014, Lima et al. 2016). Moreover, it is thought that the supplements could interact positively with the extract compounds to promote activation. A possible explanation for the activation observed in M. nigra without supplements may be the presence of rutin in the extract. Rutin increases the survival and prevents the decrease of proliferation of neural crest stem cells after damage caused by aflatoxin during in vitro culture (Nones et al. 2015). 


\section{CONCLUSIONS}

Despite follicle loss after culturing, overall, our findings appear to suggest that the remaining follicles cultured at $0.1 \mathrm{mg} / \mathrm{mL}$ of Morus nigra extract were in good condition and able to resume their development, as demonstrated by the same rates of DNA damage as the control medium and by primordial follicle activation.

Due to the higher cost of $\alpha$-MEM (about 40 times more expensive), we recommend the use of M. nigra as a culture medium under the condition tested.

Acknowledgements.- The authours thank the Bruna B. Gouveia holds a scholarship from the Fundação de Amparo à Ciência e Tecnologia do Estado de Pernambuco (FACEPE) of Brazil, Jackson R.G.S. Almeida and Maria Helena T. Matos are supported by a grant from Conselho Nacional de Desenvolvimento Científico e Tecnológico (CNPq).

Conflict of interest statement. - The authors have no competing interests.

\section{REFERENCES}

Barberino R.S., Barros V.R., Menezes V.G., Santos L.P., Araújo V.R., Queiroz M.A., Almeida J.R., Palheta R.C. \& Matos M.H. 2016. Amburana cearensis leaf extract maintains survival and promotes in vitro development of ovine secondary follicles. Zygote 24(2):277-285. <http://dx.doi.org/10.1017/ S0967199415000179><PMid:26083197>

Berrocal D.D., Revilla J.L., Sá N.R., Matos M.H.T., Celestino J.J.H., Alves B.G. \& Figueiredo J.R. 2016. Insulin levels affect the in vitro survival and development of preantral follicles cultured in situ in the presence of goat bone morphogenetic protein 15 and/or growth and differentiation factor 9. Anim. Reprod. 13(3):540-540.

Carocho M. \& Ferreira I.C.F.R. 2013. A review on antioxidants, prooxidants and related controversy: natural and synthetic compounds, screening and analysis methodologies and future perspectives. Food Chem. Toxicol. 51:1525. <http://dx.doi.org/10.1016/j.fct.2012.09.021><PMid:23017782>

Cavalcante A.Y.P., Barberino R.S., Gouveia B.B., Bezerra M.É.S., Menezes V.G., Souza G.R., Rolim L.A., Rolim-Neto P.J., Almeida J.R.G.S. \& Matos M.H.T. 2017. Effect of ovarian tissue storage in Morus nigra extract on the morphology and DNA fragmentation of ovine preantral follicles. Semina, Ciênc. Agrárias 38(4):1973-1986.

Chaves R.N., Martins F.S., Saraiva M.V., Celestino J.J., Lopes C.A., Correia J.C., Verde I.B., Matos M.H., Báo S.N., Name K.P., Campello C.C., Silva J.R. \& Figueiredo J.R. 2008. Chilling ovarian fragments during transportation improves viability and growth of goat preantral follicles cultured in vitro. Reprod. Fertil. Develop. 20(5):640-647. <http://dx.doi.org/10.1071/ RD07195><PMid:18577361>

Devine P.J., Perreault S.D. \& Luderer U. 2012. Roles of reactive oxygen species and antioxidants in ovarian toxicity. Biol. Reprod. 86(2):27. <http://dx.doi. org/10.1095/biolreprod.111.095224><PMid:22034525>

Ercisli S. \& Orhan E. 2007. Chemical composition of white (Morus alba), red (Morus rubra) and black (Morus nigra) mulberry fruits. Food Chem. 103(4):1380-1384.<http://dx.doi.org/10.1016/j.foodchem.2006.10.054>

Furlong H.C., Stämpfli M.R., Gannon A.M. \& Foster W.G. 2015. Cigarette smoke exposure triggers the autophagic cascade via activation of the AMPK pathway in mice. Biol. Reprod. 93(4):93. <http://dx.doi.org/10.1095/ biolreprod.115.132183><PMid:26377221>

Gouveia B.B., Macedo T.J.S., Santos J.M.S., Barberino R.S., Menezes V.G., Müller M.C., Almeida J.R., Figueiredo J.R. \& Matos M.H. 2016. Supplemented base medium containing Amburana cearensis associated with FSH improves in vitro development of isolated goat preantral follicles. Theriogenology 86(5):1275-1284. <http://dx.doi.org/10.1016/j.theriogenology.2016.04.068> $<$ PMid:27287468>
Gupta P.S.P., Ramesh H.S., Manjunatha B.M., Nandi S. \& Ravindra J.P. 2008. Production of buffalo embryos using oocytes from in vitro grown preantral follicles. Zygote 16(1):57-63. <http://dx.doi.org/10.1017/ S096719940700442X><PMid:18221582>

Haag K.T., Magalhaes-Padilha D.M., Fonseca G.R., Wischral A., Gastal M.O., King S.S., Jones K.L., Figueiredo J.R. \& Gastal E.L. 2013. Equine preantral follicles obtained via the Biopsy Pick-Up method: histological evaluation and validation of a mechanical isolation technique. Theriogenology 79(5):735-743.<http://dx.doi.org/10.1016/j.theriogenology.2012.10.023> $<$ PMid:23352704>

Lima L.F., Rocha R.M., Alves A.M., Carvalho A.A., Chaves R.N., Lopes C.A., Báo S.N., Campello C.C., Rodrigues A.P. \& Figueiredo J.R. 2016. Comparison between the additive effects of diluted (rFSH) and diluted/dynamized (FSH $6 \mathrm{cH}$ ) recombinant follicle-stimulating hormone on the in vitro culture of ovine preantral follicles enclosed in ovarian tissue. Revta Complementary Therap. Med. 25:39-44. <http://dx.doi.org/10.1016/j.ctim.2015.12.016> <PMid:27062946>

Lins T.L.B.G., Cavalcante A.Y.P., Santos J.M.S., Menezes V.G., Barros V.R.P., Barberino R.S., Bezerra M.E.S., Macedo T.J.S. \& Matos M.H.T. 2017. Rutin can replace the use of three other antioxidants in the culture medium, maintaining the viability of sheep isolated secondary follicles. Theriogenology 89:263-270.<http://dx.doi.org/10.1016/j.theriogenology.2016.11.019> $<$ PMid:28043362>

Luyckx V., Dolmans M.M., Vanacker J., Legat C., Moya C.F., Donnez J. \& Amorim C.A. 2014. A new step toward the artificial ovary: survival and proliferation of isolated murine follicles after autologous transplantation in a fibrin scaffold. Fertil Steril. 101(4):1149-1156. <http://dx.doi.org/10.1016/j. fertnstert.2013.12.025><PMid:24462059>

Magalhães D.M., Duarte A.B.G., Araújo V.R., Brito I.R., Soares T.G., Lima I.M., Lopes C.A., Campello C.C., Rodrigues A.P. \& Figueiredo J.R. 2011. In vitro production of a caprine embryo from a preantral follicle cultured in media supplemented with growth hormone. Theriogenology 75(1):182-188. <http:// dx.doi.org/10.1016/j.theriogenology.2010.08.004> <PMid:20875671>

Mata-Campuzano M., Alvarez-Rodríguez M., Olmo E., Fernández-Santos M.R., Garde J.J. \& Martínez-Pastor F. 2012. Quality, oxidative markers and DNA damage (DNA) fragmentation of red deer thawed spermatozoa after incubation at $37 \mathrm{C}$ in presence of several antioxidants. Theriogenology 78(5):1005-1019. <http://dx.doi.org/10.1016/j.theriogenology.2011.12.018> <PMid:22818091>

Mazimba O., Majinda R.R.T. \& Motlhanka D. 2011. Antioxidant and antibacterial constituents from Morus nigra. African J. Pharm. Pharmacol. 5(6):751-754 <http://dx.doi.org/10.5897/AJPP11.260>

Moretti E., Mazzi L., Terzuoli G., Bonechi C., Iacoponi F., Martini S., Rossi C. \& Collodel G. 2012. Effect of quercetin, rutin, naringenin and epicatechin on lipid peroxidation induced in human sperm. Reprod. Toxicol. 34(4):651-657. <http://dx.doi.org/10.1016/j.reprotox.2012.10.002><PMid:23064111>

Naderi G.A., Asgary S., Sarraf-Zadegan N., Oroojy H. \& Afshin-Nia F. 2004. Antioxidant activity of three extracts of Morus nigra. Phytotherapy Res. 18(5):365-369. <http://dx.doi.org/10.1002/ptr.1400><PMid:15173994>

Nafees S., Rashid S., Ali N., Hasan S.K. \& Sultana S. 2015. Rutin ameliorates cyclophosphamide induced oxidative stress and inflammation in Wistar rats: role of NFKB/MAPK pathway. Chemico Biolog. Interact. 231:98-107. <http://dx.doi.org/10.1016/j.cbi.2015.02.021> <PMid:25753322>

Nickavar B. \& Mosazadeh G. 2010. Influence of three morus species extracts on $\alpha$-amylase activity. Iranian J. Pharm. Res. 8(2):115-119.

Nones J., Nones J. \& Trentin A. 2015. Rutin increases neural crest stem cell survival against damage caused by alatoxin B1. Biotemas 28(4):1-8. <http://dx.doi.org/10.5007/2175-7925.2015v28n4p1>

Peng X., Yang M., Wang L., Tong C. \& Guo Z. 2010. In vitro culture of sheep lamb ovarian cortical tissue in a sequential culture medium. J. Assisted Reprod. Gen. 27(5):247-257. <http://dx.doi.org/10.1007/s10815-0109415-6><PMid:20393796> 
Picton H.M., Harris S.E., Muruvi W. \& Chambers E.L. 2008. The in vitro growth and maturation of follicles. Reprod. 136(6):703-715. <http://dx.doi. org/10.1530/REP-08-0290> <PMid:19074213>

Radojković M., Zeković Z., Mašković P., Vidović S., Mandić A., Mišan A. \& Đurović S. 2016. Biological activities and chemical composition of Morus leavesextracts obtained by maceration and supercritical fluid extraction. J. Supercritical Fluids 117:50-58. <http://dx.doi.org/10.1016/j.supflu.2016.05.004>

Regasini L.O., Vellosa J.C., Silva D.H., Furlan M., Oliveira O.M., Khalil N.M., Brunetti I.L., Young M.C., Barreiro E.J. \& Bolzani V.S.. 2008. Flavonols from Pterogyne nitens and their evaluation as myeloperoxidase inhibitors. Phytochemistry 69(8):1739-1744.<http://dx.doi.org/10.1016/j.phytochem.2008.01.006> <PMid:18395762>

Santos J.M.S., Menezes V.G., Barberino R.S., Macedo T.J.S., Lins T.L.B., Gouveia B.B., Barros V.R., Santos L.P., Gonçalves R.J. \& Matos M.H. 2014 Immunohistochemical localization of fibroblast growth factor-2 in the sheep ovary and its effects on pre-antral follicle apoptosis and development in vitro. Reprod. Domest. Anim. 49(3):522-528. <http://dx.doi.org/10.1111/ rda.12322><PMid:24750547>

Serafim M.K., Araújo V.R., Silva G.M., Duarte A.B., Almeida A.P., Chaves R.N., Campello C.C., Lopes C.A., Figueiredo J.R. \& Silva L.D.. 2010. Canine preantral follicles cultured with various concentrations of follicle-stimulating hormone (FSH). Theriogenology 74(5):749-755. <http://dx.doi.org/10.1016/j. theriogenology.2010.03.028> <PMid:20537700>

Silva J.R., van den Hurk R., Matos M.H., Santos R.R., Pessoa C., Moraes M.O. \& Figueiredo J.R. 2004. Influences of FSH and EGF on primordial follicles during in vitro culture of caprine ovarian cortical tissue. Theriogenology 61(9):1691-1704.<http://dx.doi.org/10.1016/j.theriogenology.2003.09.014> <PMid:15019464>

Soundararajan R., Wishart A.D., Rupasinghe H.V., Arcellana-Panlilio M., Nelson C.M., Mayne M. \& Robertson G.S. 2008. Quercetin 3-glucoside protects neuroblastoma (SH-SY5Y) cells in vitro against oxidative damage by inducing sterol regulatory element-binding protein-2-mediated cholesterol biosynthesis. J. Biol. Chem. 283(4):2231-2245. <http://dx.doi.org/10.1074/ jbc.M703583200> <PMid:18032389>

Sreejalekshmi P., Raghavendra B.S., Subramani T.S., Murthy V.C., Jamuna K.V., Prasad R.V., Ravindra J.P. \& Selvaraju S. 2011. Detection of follicular apoptosis in water buffalo (Bubalus bubalis) ovary by histology and nick end labelling technique. Reprod. Domest. Anim. 46(1):59-65. <http:// dx.doi.org/10.1111/j.1439-0531.2009.01569.x><PMid:20070580>

Turan I., Demir S., Kilinc K., Burnaz N.A., Yaman S.O., Akbulut K., Mentese A., Aliyazicioglu Y. \& Deger O. 2017. Antiproliferative and apoptotic effect of Morus nigra extract on human prostate cancer cells. Saudi Pharmaceutical J. 25(2):241-248. <http://dx.doi.org/10.1016/j.jsps.2016.06.002> $<$ PMid:28344475>

Wang C. \& Roy S.K. 2007. Development of Primordial Follicles in the Hamster: Role of Estradiol-17ß. Endocrinol. Neurochem. Int. 148(4):1707-1716. <PMid:17194746>

Wang C.P., Li J.L., Zhang L.Z., Zhang X.C., Yu S., Liang X.M., Ding F. \& Wang Z.W. 2013. Isoquercetin protects cortical neurons from oxygen-glucose deprivation, reperfusion induced injury via suppression of TLR4-NF-кB signal pathway. Neurochem. Int. 63(8):741-749. <http://dx.doi.org/10.1016/j. neuint.2013.09.018> <PMid:24099731> 